\title{
ANALYSIS OF EQUINE BEHAVIOR PATTERN OF RECREATIONAL AND SPORT HORSES UNDER SADDLE UTILIZATION
}

\author{
Laboratory of Horse Breeding and Animal Assisted Therapy, West Pomeranian University \\ of Technology, Szczecin, Poland \\ ${ }^{1}$ Department of Horse Breeding and Use, University of Life Science in Lublin, Poland
}

\begin{abstract}
The aim of the study was to analyze the behavior of recreational and sport horses in three different seasons of their riding use. The observations included 15 geldings and mares, in that 9 horses used for recreation and 6 sport horses used in jumping over an obstacle (L-C class). The horses were managed in the same environmental conditions, in the same riding center. The observations of horse behavioral responses were carried out three times, i.e. observation I - before the summer season, observation II - during the holiday time, observation III - beyond the summer season which is the period of the lowest workload of horses used for leisure (December). Horse behavior pattern was assessed towards mounting a horse by a rider, tighten the girth as well as aids-related responses, reaction to bending and finally, jumping over an obstacle. Besides, the behavior of horses used for recreational activities was evaluated when a rider was working the horse on the lunge line. The equine behavior pattern was assessed on the scale of 1 to 3 points, when $1 \mathrm{pt}$ meant the undesirable, negative refusal to perform a task, aggressive tendencies, $2 \mathrm{pt}$ - accteptable reaction, small signs of disobedience or anxiety, pinned back ears, wagging tail showing irritation, delayed reaction to the aids etc., whereas 3 pts desirable behavior, willing to execute tasks, displaying full acceptance of aids, etc. It was found that sport horses showed better behavior in the range of the parameters evaluated. The horses used for recreation purposes earned significantly lower scores for the behavior at the extended working time, that is during the holiday season when average working time length was $3.58 \mathrm{~h} /$ day. There was observed a significant correlation between the working time of horses used for leisure in the summer period and the behavior scores. The worse scores obtained by the leisure horses were most probably the effect of carrying a higher number of riders of different skills levels and the extended working time.
\end{abstract}

Key words: horse behavior, horse use, utilization for recreation, sport use.

\section{INTRODUCTION}

It appears clearly that horse suitability for different use forms as well as equine behavior pattern at work and care services are affected by several factors. The past few decades have been marked by growth in numbers of horses in a wide variety of uses other than farming (Jezierski et al. 2006; Wolińska et al. 2012). Horses` responses to their different environments, that is under saddle (Ignor et al. 2011; Wolińska et al. 2012; Przybyłowicz et al. 2013; Cieśla et al. 2017) and at the stable or paddocks (Jezierski et al. 2006; Ninomiya et al. 2008; Górecka-Bruzda i in. 2013; Stachurska et al. 2016) were analyzed thoroughly. Lately much

Corresponding author: Angelika Cieśla, Laboratory of Horse Breeding and Animal Assisted Therapy, West Pomeranian University of Technology, Szczecin, Doktora Judyma 12, 71-466 Szczecin, Poland, e-mail: Angelika.ciesla@zut.edu.pl 
research has been conducted into the area of the stereotypic behaviors observed among horses (Kiley-Worthington 1983; Houpt 1986; Luescher et al. 1998; Bachmann et al. 2003; Nowicka-Posłuszna and Ziomko 2012).

The objective of the present study was the analysis of equine behavior at horseback riding-related activities subject to a horse utilization form (recreation, sport), season (observations carried out three times) and ridden work time.

\section{MATERIAL AND METHODS}

The assessment included 15 warmbloods (geldings and mares) working under saddle, in that 9 horses aged 8-18 yrs used for recreational purposes; 6 horses aged 4-10 yrs engaged in jumping over obstacles, class $\mathrm{L}-\mathrm{C}$. The horses were managed under the same environmental conditions, in the same riding center, their feeding stuff complied with the official feeding standards. The observations of horses' behavior were conducted three times, namely observation I - before the summer season (April), observation II - during the summer season (last week of August), observation III - beyond the season (December) with the lowest workload of the horses used for leisure. There were assessed the horses' reponses to mounting by a rider, tighten the girth, training aids, bending (bending the body in the oblong pivot), jumping over an obstacle. Besides, the leisure riding horses were evaluated while working on the lunge line. The horses' behavior pattern was assessed on the 1-3 pt scale, where 1 point meant unwanted, negative reaction, refusal to perform a task, aggression signs, 2 pt - an accteptable reaction, small signs of disobedience or anxiety, pinned back ears, wagging tail showing irritation, delayed reaction to the aids etc., whereas 3 points desirable reaction, willingness to execute a task, full acceptance of aids, etc. The record documentation made in the center served to calculate average daily working time under saddle of horses in the eight-week periods preceding each observation. The obtained results were analyzed statistically using the Statistica 10 software package considering the means and standard deviations, establishing the significance of differences between the means as well as correlations between the average behavior scores and average ridden time of horses. The type of researches performed did not need the approval from the Local Ethics Comittee for Animal Experimentation.

\section{RESULTS}

Table 1 and Fig. 1 present the mean behavior scores earned by the horses at particular activities during the observations. Table 1 shows that the average scores obtained by the sport horses in all three observations were higher than those reported for horses used for leisure purposes. Notably, as for the observation I and II, the differences were confirmed statistically. The scores were also more uniform as against those awarded to the horses used for recreation and sport horse group where no significant differences were determined in the average behavior scores. The leisure riding horses had significantly lower scores for the behavior assessed during observation II made in August, at the end of the summer season(average $1.84 \mathrm{pts}$ ). The highest behavior scores were given to the horses used for 
recreation during observation I conducted in April (average $2.73 \mathrm{pts}$ ). In this horse group, average behavior scores earned for particular activities differed significantly $(P \leq 0.05, P \leq 0.01)$ between the observations. At observation I, these horses obtained the higher scores for their response to the aids and behavior at jumping over the obstacle (average $3.0 \mathrm{pts}$ ), whereas most problems appeared while tighten the girth (2.33 pts on average) and working on lunge line $(2.33$ pts). Observation II highlighted significant worsening of horse behavior in all the elements, except for tighten the girth and working on the lunge. Altough the averages were smaller for the II observation with respect to the tighten the girth and working on the lunge, but there was no statistically significant difference (higher value of the standard deviation). The lowest scores were given to horses while mounting by rider and bending (1.67 pts), whereas the highest for their response to the aids $(2.00 \mathrm{pts})$. During observation III made in December, as compared to observation II, improved horses' behavior was noted in all the situations, and statistically confirmed in the case of jumping over an obstacle. As it was mentioned before, the behavior scores earned by the sport horses were definitely more uniform and ranged from 2.17 pts up to 3.0 pts.

Table 1. Statistical characteristics of behavior scores obtained by horse groups studied in particular observations

\begin{tabular}{|c|c|c|c|c|c|c|}
\hline \multirow{2}{*}{$\begin{array}{l}\text { Horse group } \\
\text { Observations }\end{array}$} & \multicolumn{3}{|c|}{$\begin{array}{l}\text { Leisure horses } \\
(\mathrm{n}=9)\end{array}$} & \multicolumn{3}{|c|}{$\begin{array}{l}\text { Sport horses } \\
(n=6)\end{array}$} \\
\hline & 1 & II & III & I & II & III \\
\hline & \multicolumn{6}{|c|}{ Mounting } \\
\hline \multirow[t]{2}{*}{$\begin{array}{c}\text { Mean } \\
\mathrm{S}\end{array}$} & $\begin{array}{c}2.78 \mathrm{~A} \\
0.44\end{array}$ & $\begin{array}{c}1.67 \mathrm{~A} \mathrm{a}^{\prime} \mathrm{b}^{\prime} \\
0.50\end{array}$ & $\begin{array}{l}2.22 \\
0.67 \\
\end{array}$ & $\begin{array}{c}2.67 \mathrm{a}^{\prime} \\
0.52\end{array}$ & $\begin{array}{c}2.67 \mathrm{~b}^{\prime} \\
0.52\end{array}$ & $\begin{array}{l}2.50 \\
0.55 \\
\end{array}$ \\
\hline & \multicolumn{6}{|c|}{ Tighten the girth } \\
\hline \multirow[t]{2}{*}{$\begin{array}{c}\text { Mean } \\
\mathrm{S}\end{array}$} & $\begin{array}{l}2.33 \\
0.87 \\
\end{array}$ & $\begin{array}{c}1.78 \mathrm{~A}^{\prime} \mathrm{B}^{\prime} \\
0.67\end{array}$ & $\begin{array}{l}2.11 \\
0.60 \\
\end{array}$ & $\begin{array}{c}3.00 \mathrm{~A}^{\prime} \\
0.00\end{array}$ & $\begin{array}{c}3.00 \mathrm{~B}^{\prime} \\
0.00\end{array}$ & $\begin{array}{l}2.17 \\
0.41\end{array}$ \\
\hline & \multicolumn{6}{|c|}{ Response to aids } \\
\hline \multirow[t]{2}{*}{$\begin{array}{c}\text { Mean } \\
\mathrm{S}\end{array}$} & $\begin{array}{c}3.00 \mathrm{Ab} \\
0.00\end{array}$ & $\begin{array}{c}2.00 \mathrm{~A} \mathrm{~A}^{\prime} \\
0.50\end{array}$ & $\begin{array}{c}2.44 \mathrm{~b} \\
0.53 \\
\end{array}$ & $\begin{array}{c}3.00 \mathrm{~A}^{\prime} \\
0.00\end{array}$ & $\begin{array}{l}2.83 \\
0.41 \\
\end{array}$ & $\begin{array}{l}2.67 \\
0.52 \\
\end{array}$ \\
\hline & \multicolumn{6}{|c|}{ Bending } \\
\hline \multirow[t]{2}{*}{$\begin{array}{c}\text { Mean } \\
\mathrm{S}\end{array}$} & $\begin{array}{c}2.78 \mathrm{a} \\
0.44 \\
\end{array}$ & $\begin{array}{c}1.67 \text { a A'B'c' } \\
0.87 \\
\end{array}$ & $\begin{array}{c}2.22 \text { d'e' } \\
0.44 \\
\end{array}$ & $\begin{array}{l}3.00 \mathrm{~A}^{\prime} \mathrm{d}^{\prime} \\
0.00\end{array}$ & $\begin{array}{c}3.00 \mathrm{~B}^{\prime} \mathrm{e}^{\prime} \\
0.00\end{array}$ & $\begin{array}{c}2.83 \mathrm{c}^{\prime} \\
0.41 \\
\end{array}$ \\
\hline & \multicolumn{6}{|c|}{ Jump } \\
\hline \multirow[t]{2}{*}{$\begin{array}{c}\text { Mean } \\
\mathrm{S}\end{array}$} & $\begin{array}{c}3.00 \mathrm{~A} \\
0.00\end{array}$ & $\begin{array}{c}1.89 \mathrm{Ab} \\
0.60\end{array}$ & $\begin{array}{c}2.78 \mathrm{~b} \\
0.44\end{array}$ & $\begin{array}{l}2.50 \\
0.55\end{array}$ & $\begin{array}{l}2.67 \\
0.52\end{array}$ & $\begin{array}{l}2.33 \\
0.82 \\
\end{array}$ \\
\hline & \multicolumn{6}{|c|}{ Working on lunge line } \\
\hline \multirow[t]{2}{*}{$\begin{array}{c}\text { Mean } \\
\mathrm{S}\end{array}$} & $\begin{array}{l}2.33 \\
0.50 \\
\end{array}$ & $\begin{array}{l}1.78 \\
0.83 \\
\end{array}$ & $\begin{array}{l}2.22 \\
0.67 \\
\end{array}$ & & & \\
\hline & \multicolumn{6}{|c|}{ Mean of all behavior elements in observations } \\
\hline $\begin{array}{l}\text { Mean } \\
\mathrm{S}\end{array}$ & $\begin{array}{c}2.73 \mathrm{a} \\
0.51\end{array}$ & $\begin{array}{l}1.84 \mathrm{a} \mathrm{a}^{\prime} \mathrm{b}^{\prime} \\
0.65\end{array}$ & $\begin{array}{l}2.41 \\
0.59\end{array}$ & $\begin{array}{c}2.83 a^{\prime} \\
0.38\end{array}$ & $\begin{array}{c}2.83 \mathrm{~b} \\
0.38\end{array}$ & $\begin{array}{l}2.56 \\
0.56\end{array}$ \\
\hline
\end{tabular}

Values in lines, within a given horse group denoted by the same small letters a, b... differ significantly at $P \leq 0.05$; by capital letters $A, B \ldots$ differ significantly at $P \leq 0.01$.

Values in lines between two horse groups denoted by the same small letters a', b'... differ significantly at $P \leq 0.05$; by capital letters $A^{\prime}, B^{\prime} \ldots$ differ significantly at $P \leq 0.01$. 


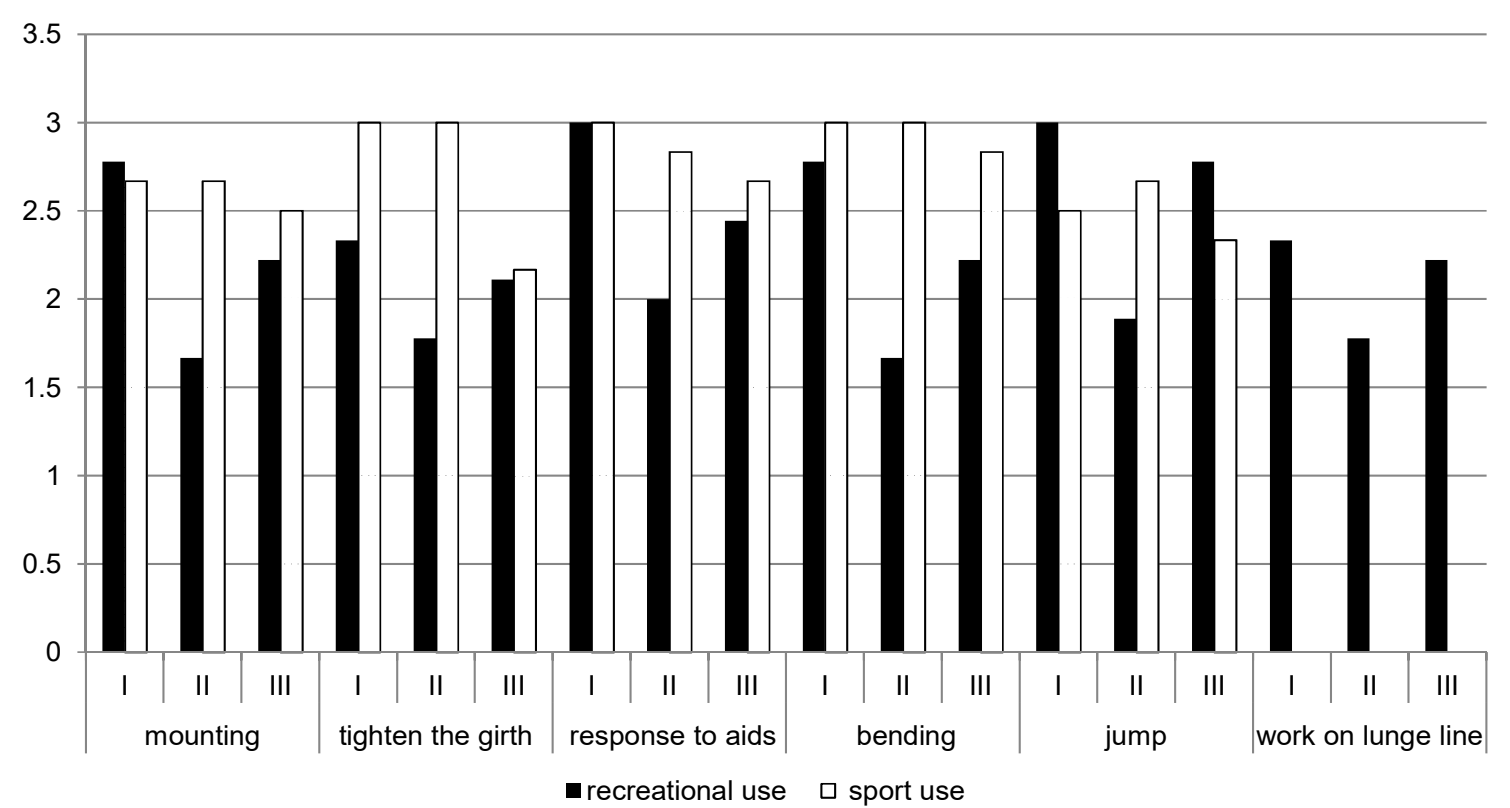

I, II, III - observations

Fig. 1. Mean behavior scores for horses used for recreation and sport during particular observation

Table 2 compares average working time of horses in the periods preceding the observations and the correlations between the avergae working time and the means obtained by the horses at particular observations. Figures 2 and 3 are graphical representations of the research results. As Table 2 indicates the horses used for leisure worked significantly longer over the summer season (on average $3.58 \mathrm{~h} /$ day) as compared to the spring and autumn period (I and III observations). Significant correlation between the behavior scores earned for this period and the working time was noted. Figure 2 demonstrates that the average highest scores given for horses ' behavior during observation I were correlated to the lowest average working time. The lowest scores had the horses in the summer season characterized by the highest ridden work level. Figure 3 indicates that the work time of sport horses was uniform over the studied period, that is 2 hours a day. There were not noted any significant correlations between the average working time of these horses and their behavior scores.

Table 2. Average working time of horses ( $h /$ day) in particular observations and correlation value $(r)$ between the time and scores obtained

\begin{tabular}{|c|c|c|c|c|c|c|}
\hline \multirow{2}{*}{$\begin{array}{l}\text { Hourse group } \\
\text { Observations }\end{array}$} & \multicolumn{3}{|c|}{$\begin{array}{l}\text { Leisure horses } \\
\qquad(n=9)\end{array}$} & \multicolumn{3}{|c|}{$\begin{array}{c}\text { Sport horses } \\
(n=6)\end{array}$} \\
\hline & I & II & III & I & II & III \\
\hline & \multicolumn{6}{|c|}{ Average working time } \\
\hline $\begin{array}{c}\text { Mean } \\
\mathrm{S}\end{array}$ & $\begin{array}{c}1.64 \mathrm{AB} \\
0.26\end{array}$ & $\begin{array}{c}3.58 \mathrm{BC} \\
0.42\end{array}$ & $\begin{array}{c}2.61 \mathrm{AC} \\
0.42\end{array}$ & $\begin{array}{l}1.87 \\
0.27\end{array}$ & $\begin{array}{l}2.07 \\
0.19\end{array}$ & $\begin{array}{l}2.00 \\
0.24\end{array}$ \\
\hline S & \multicolumn{6}{|c|}{ Correlation: working time-scores } \\
\hline$r$ & 0.15 & $0.44^{*}$ & 0.17 & 0.18 & -0.22 & 0.07 \\
\hline
\end{tabular}

Values within a horse group denoted by the same capital letters $A, B \ldots$ differ significantly at $P \leq 0.01$.

*significant at $\mathrm{P} \leq 0.01$. 


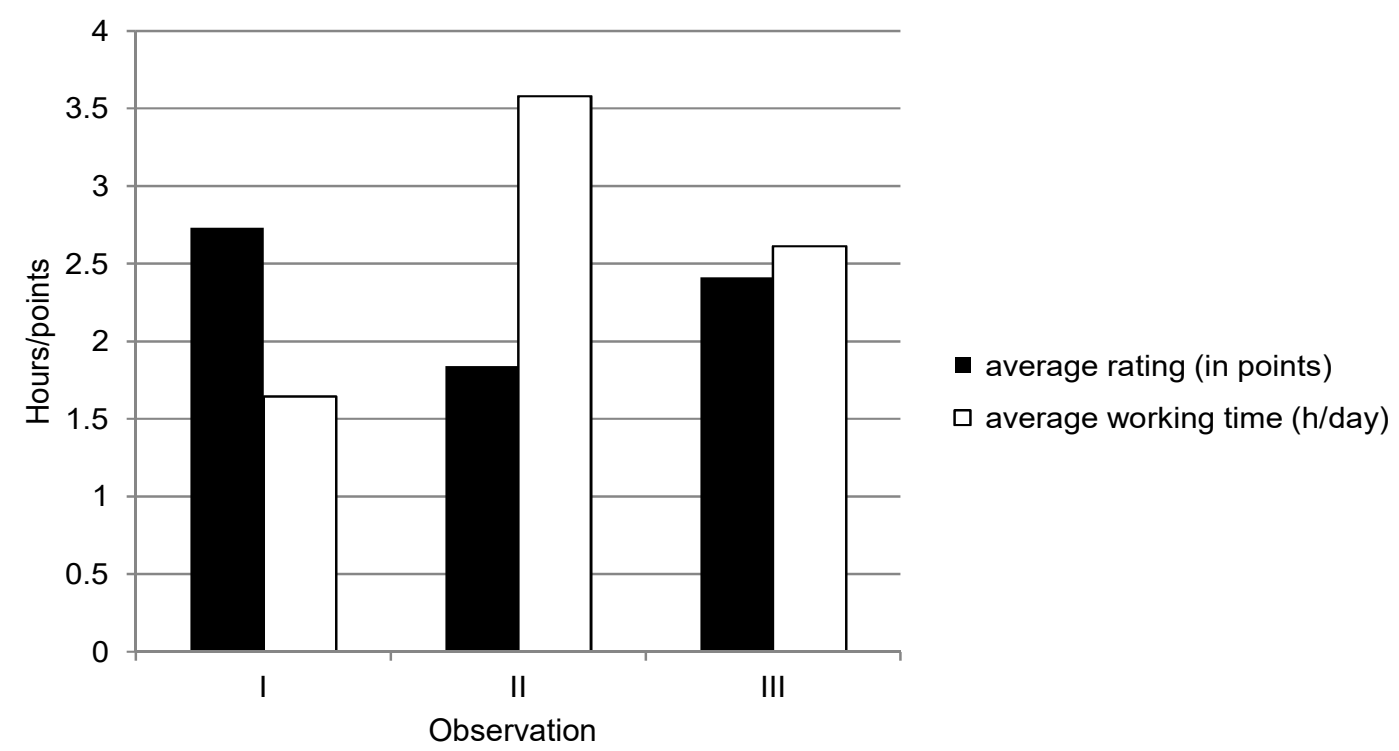

Fig. 2. Tabulation of average working time and behavior scores for horses used for recreation

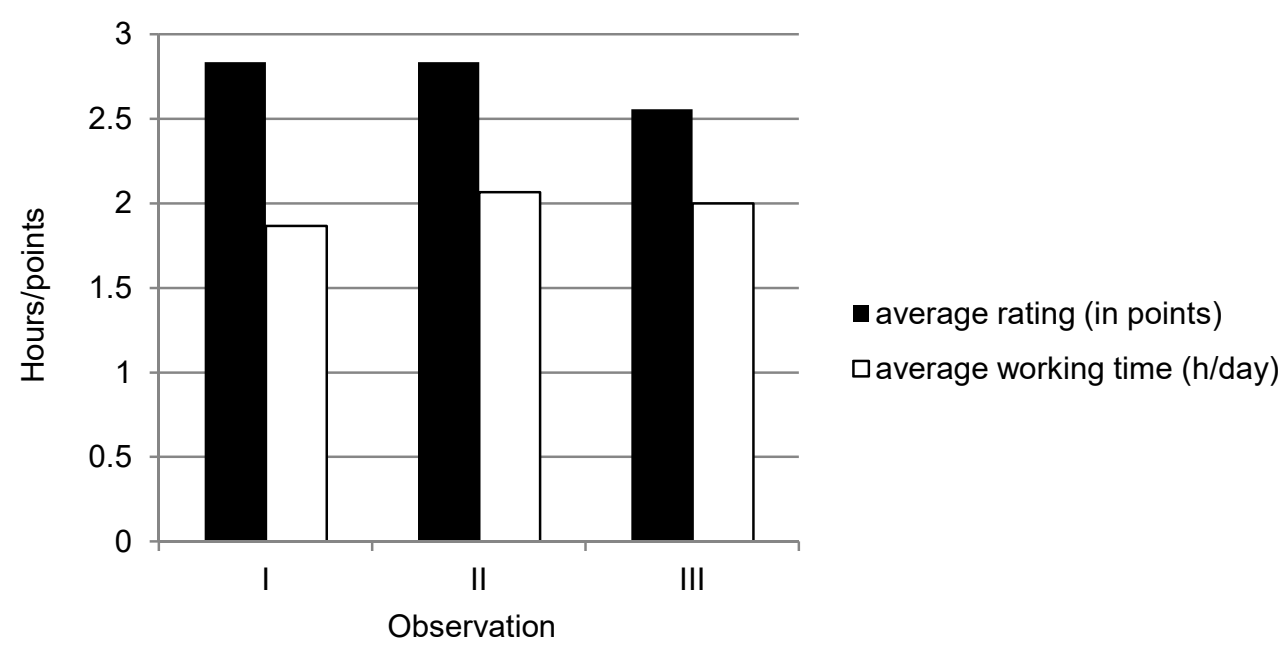

Fig. 3. Tabulation of average working time and behavior scores for sport horses

\section{DISCUSSION}

Research conducted by Górecka-Bruzda et al. (2011) have shown that riders, especially recreational riders, definitely prefer horses that are friendly, easy manageable and comfortable during saddle utilization. The tables and figures show that sport horses obtained higher and more uniform behavior scores as compared to those given to the horses used for leisure. The horse's responses were assessed towards an approaching stranger, cleaning activities, leg grooming, bridling, saddling and working under the saddle. Similar results were reported in the earlier studies which assessed the equine behavior pattern on an approaching stranger, cleaning activities, leg grooming, putting the bridle on, saddling and working under the saddle (Cieśla et al. 2017). The sport horses evaluated in the mentioned above studies were given higher behavior scores compared to the horses for recreation. 
Considering the horses from both, the earlier studies and the present research, the sport horses had their permanent experienced riders, whereas horses for recreational riding carried a higher number of riders of different skills levels, in that beginners. Negative effect of too many riders on the behavior of leisure riding horses was reported by Walendowska and Nowicka-Posłuszna (1991). The authors state that horses used for recreational riding are often exposed to a contact with riders of inadequate skills that triggers worsening of horse behavior during the grooming activities, tighten the girth, horse saddling and mounting.

As Table 1 and Fig. 1 illustrate, the extended summer working time of horses used for leisure combined with more intense rotation of riders led to significantly lower behavior scores during observation II. Similar findings were obtained in the earlier studies where the recreational horses earned the best scores before the holiday season onset, while during the holiday time when horse workload was $4 \mathrm{~h}$ a day on average, their behavior worsened at stranger's approach, cleaning activities, saddling, putting the bridle on and ridden work (Cieśla et al. 2017). However, Przybyłowicz et al. (2013) did not observe any changes in the behavior of horses for leisure while working under saddle over the holiday season, while at reining (bitting), saddling and grooming operations, the behavior improved slightly.

Table 1 and Fig. 1 indicate that horse behavior at mounting appeared to be one with the lowest scores given to leisure riding horses for their work in the summer. Wolińska et al. (2012) analyzed behavior of horses used for recreational purposes in some centers in north-eastern Poland and, according to the riders` surveys, concluded that only $27 \%$ of horses did not display any negative violent reactions at mounting. The authors highlight that novice riders wearing the pointed toe boots or moving up and down in the saddle violently can actually bring discomfort or even hurt a horse. This situation in turn, triggers a defense reaction in animal which human recognizes as an undesirable response. The authors findings showed that nearly $50 \%$ of horses under study fidget around at mounting, $26 \%$ start when a rider puts his foot in the stirrup and $23 \%$ start when a rider gets down in the saddle. Other unwanted behaviors observed at mounting and reported by the authors include head jerking, strong tail swishing, attempted bite and kick (Wolińska et al. 2012). In the present study, the significant worsening of recreational horses behavior during the summer season (observation II) was noted as regards all the elements comprising the under saddle work, that is reaction to the aids, bending and behavior at jumping over an obstacle. The difference in behavior scores was not confirmed statistically only for working on the lunge line and doing up the girth. Alike the earlier studies of the present authors, worsening of behavior of leisure riding horses was observed in the summer period, the time of the increased workload (Cieśla et al. 2017). The research of Ignor et al. (2011) assessing the behavior of horses intended for recreational activities at walk and trot did not indicate or indicated only slight worsening of behavior pattern during the holiday season. Wolińska et al. (2012) found that only $30 \%$ of leisure riding horses did not exhibit any undesirable behaviors at ridden work. The most common problems the riders face include rushiness, attempted bolting and a high head position. Out of 9 leisure riding horses under study, 3 horses started to demonstrate the following vices in the summer season: biting, kicking and bucking. The studies of Wolińska et al. (2012) showed that $13 \%$ of horses tried to kick each other and $15 \%$ attack and bite, while „sheep jumps" were observed in $21 \%$ of horses used for recreation. 
It is well recognized that the horse is a species which developed locomotory adaptations through evolution (Walendowska and Nowicka-Posłuszna 1991; Jezierski et al. 2006; Zeitler-Feicht 2008), thus free access to paddocks and pastures has beneficial effect on horse behavior while limited access can lead to behavioral problems occurrence (Zeitler-Feicht 2008; Wolińska et al. 2012). Wolińska et al. (2012) report that horses should be provided with minimum 4 hours of free movement daily in a pasture to meet the basic biological needs. The under saddle work of a horse is a form of forced movement and importantly, the work itself does not ensure free movement and will never satisfy horse's exercise requirement (Zeitler-Feicht 2008). In the present study, the horses stayed in the paddocks for about 4 hours a day. The ridden horse group worked significantly longer at the holiday season and was given significantly lower behavior scores at that time. Contrary to the results presented in Table 2, Ignor et al. (2011) indicated moderate, but not confirmed statistically, correlations between the time of leisure horse work and the behavior scores obtained for ridden work and grooming chores. The horses under study were managed in different stables, with different workload levels and length of time spent in the paddocks. The authors of the studies mentioned above attributed the higher behavior scores of horses to longer time spent in the paddocks.

\section{RECAPITULATION}

There are only few works addressing the behavior of leisure riding horses and sport horses, yet as the methodologies of the observations performed differ markedly, full interpretation of the results obtained in the present study is rather impossible. The analysis carried out indicated that extending the under saddle work time of horses used for recreational purposes in the summer season had negative effect on equine behavior pattern. In the summer season the horses earned the lowest behavior scores for all the elements of the behavior pattern and mostly for responses to mounting, rider's aids, jumping and bending. After the summer season when the ridden horse work was shortened, the horses ' behavior improved. The working time of sport horses was uniform during the study period and the horse behavior assessed significantly higher as compared to the leisure riding horses. Apart from the shorter time of the under saddle work, the obtained results may have been the consequence of mounting the leisure riding horses by a higher number of riders of different skills levels.

\section{REFERENCES}

Bachmann I., Audigé L., Stauffacher M. 2003. Risk factors associated with behavioural disorders of crib-biting, weaving and box-walking in Swiss horses. Equine Vet. J. 35(2), 158-163.

Cieśla A., Pluta M., Maj P. 2017. Horse behaviour pattern at holiday time subject to its utilization form and morphological type. Acta Sci. Pol. Zoot. 16(4), 5-10.

Górecka-Bruzda A., Jastrzębska E., Muszyńska A., Jędrzejewska E., Jaworski Z., Jezierski T., Murphy J. 2013. To jump or not to jump ? Strategies employed by leisure and sport horses. J. Veter. Behav., Clinical Applications and Research 8(4), 253-260.

Górecka-Bruzda A., Jaworski Z., Golonka M., Jezierski T., Długosz B., Pieszka M. 2011. Looking for an ideal horse: rider preferences. Anthrozoös 24, 379-392. 
Houpt K. 1986. Stable vices and trailer problems. Vet. Clinics of North America, Equine Pract. 2/3, 623-633.

Ignor J., Cieśla A., Sarol A. 2011. Effect of the length of working time in recreationally used horses on their bahaviour in selected horse riding centers. J. Food, Agriculture and Environment JFAE 9(2), 449-451.

Jezierski T., Jaworski Z., Górecka A. 2006. Zachowanie się koni i jego wpływ na użytkowanie sportowe i rekreacyjne [Horse behavior and its effect on sport and leisure use]. Prz. Hod. 9, 11-17. [in Polish]

Kiley-Worthington M. 1983. Stereotypes on horses. Equine Pract. 5, 34-40.

Luescher U.A., McKeown D.B., Dean H. 1998. A cross-sectional study on compulsive behavoiur (stable vices) in horses. Equine Vet. J., Suppl. 27, 14-18.

Ninomiya S., Aoyama M., Ujiie Y., Kusunose R., Kuwano A. 2008. Effects of bedding material on the lying behavior in stabled horses. J. Equine Sci. 19(3), 53-56.

Nowicka-Posłuszna A., Ziomko K. 2012. Stereotypies and undesirable behaviours in horses used for sports and leisure activities. Ann. UMCS, Sectio EE, 30(4), 124-134.

Przybyłowicz N., Cieśla A., Kożuszek L., Ignor J. 2013. Analiza wpływu użytkowania rekreacyjnego w sezonie wakacyjnym na zachowanie koni, w: Międzynarodowa Konferencja Naukowa „Innowacyjność w naukach o zwierzętach”, Kraków, 20-21 czerwca 2013. [b.w.], 212-213. [in Polish]

Stachurska A., Kowalska N., Kolstrung R., Pluta M. 2016. Time of lying in the horse with regard to its sex and system of management. Acta Sci. Pol., Zootechnica 15(2), 77-86.

Walendowska A., Nowicka-Posłuszna A. 1991. Ocena niektórych zachowań koni wierzchowych [Assessment of some behaviors of ridden horses]. Koń Pol. 3(115), 9-10. [in Polish]

Wolińska K., Łuczyńska M., Jaworski Z. 2012. Analiza zaburzeń behawioralnych u koni rekreacyjnych w wybranych ośrodkach jeździeckich województwa pomorskiego i warmińsko-mazurskiego [Analysis of behavioral disturbances of leisure horses in some riding centers in Pomeranian and Warmian-Masurian Districts]. Rocz. Nauk. PTZ 8(1), 73-81. [in Polish]

Zeitler-Feicht M. 2008. Handbuch Pferdeverhalten. Eugen Ulmer KG, Stuttgart, Germany.

\section{ANALIZA ZACHOWANIA KONI REKREACYJNYCH I SPORTOWYCH PODCZAS JAZDY WIERZCHEM}

Streszczenie. Celem pracy była analiza zachowania koni rekreacyjnych i sportowych w trzech różnych sezonach ich użytkowania wierzchowego. Obserwacjami objęto 15 wałachów i klaczy, w tym 9 koni użytkowanych rekreacyjnie i 6 koni użytkowanych sportowo, startujących w skokach przez przeszkody (klasy $L-C$ ). Konie utrzymywane były w jednym ośrodku jeździeckim, w tych samych warunkach środowiskowych. Obserwacje zachowania koni przeprowadzono 3-krotnie: obserwacja I - przed sezonem letnim, obserwacja II - w okresie wakacji letnich, obserwacja III - poza sezonem, w okresie najmniej intensywnej pracy w przypadku koni użytkowanych rekreacyjnie (w grudniu). Oceniano zachowanie koni podczas: wsiadania jeźdźca, podciągania popręgu, reakcji konia na pomoce, zgięcie, zachowania w czasie skoku przez przeszkodę. Ponadto u koni użytkowanych rekreacyjnie oceniono ich zachowanie $w$ trakcie pracy z jeźdźcem na lonży. Zachowanie koni oceniano w skali od 1 do 3 punktów, gdzie 1 punkt oznaczał reakcję niepożądaną, negatywną, odmowę wykonania zadania, przejawy agresji, 2 punkty oznaczały reakcję akceptowalną, drobne przejawy nieposłuszeństwa, niepokoju, tulenie uszu, machanie ogonem wskazujące na irytację, oporną lub spóźnioną reakcję na pomoc itp., a 3 punkty - reakcję pożądaną, chętne wykonanie zadania, pełną akceptację pomocy itp. Stwierdzono, że konie użytkowane sportowo charakteryzują się lepszym zachowaniem w zakresie ocenianych parametrów. Konie 
użytkowane rekreacyjnie uzyskały istotnie niższe noty za zachowanie w okresie wydłużonego czasu pracy, czyli w czasie wakacji letnich, gdy średni czas pracy koni wynosił 3,58 h/dzień. Stwierdzono istotną korelację pomiędzy czasem pracy koni rekreacyjnych w okresie letnim a ocenami za zachowanie. Na pogorszenie wyników koni użytkowanych rekreacyjnie najprawdopodobniej wpłynęła większa liczba jeźdźców o różnym poziomie zaawansowania oraz wydłużenie czasu pracy.

Słowa kluczowe: zachowanie koni, użytkowanie koni, użytkowanie rekreacyjnie, użytkowanie sportowe. 
